\section{The nexus between firm size, growth and profitability: new panel data evidence from Asia-Pacific markets}

Firm size, growth and profitability

\author{
Inder Sekhar Yadav
}

Department of Humanities and Social Sciences, Indian Institute of Technology Kharagpur, Kharagpur, India

Debasis Pahi

School of Commerce and Economics,

Kalinga Institute of Industrial Technology (KIIT) Deemed to be University,

Bhubaneswar, India, and

Rajesh Gangakhedkar

Institute of Public Enterprise, Hyderabad, India

\begin{abstract}
Purpose - The purpose of this paper is to examine the correlation between firm size, growth and profitability along with other firm-specific variables (like leverage, competition and asset tangibility), macroeconomic variable (like GDP growth-business cycle) and stock market development variable (like MCR).

Design/methodology/approach - Using the COMPUSTAT Global database this work uses panel dynamic fixed effects model for nearly 12,001 unique non-financial listed and active firms from 1995 to 2016 for 12 industrial and emerging Asia-Pacific economies. This interrelationship was also examined for small, medium and large size companies classified based on three alternate measures such as total assets, net sales and MCR of firms.

Findings - The persistence of profits coefficient was found to be positive and modest. There is evidence of a negative size-profitability and positive growth-profitability relationship suggesting that initially profitability increases with the growth of the firm but eventually, overtime, gains in profit rates reduce, as size increases indicting that large size breeds inefficiency. The relationship between firm's leverage ratio and its asset tangibility is found to be negative with profitability. The business cycle and stock market development variables suggest a positive relationship with the profitability of firms. However, the significance of estimated coefficients was mixed and varied among different selected Asia-Pacific economies.

Practical implications - The study has economic implications on issues such as industrial concentration, risk and optimum size of firms for practicing managers of modern enterprise in emerging markets.

Originality/value - The analysis of the relationship between the firm size, growth and profitability is uniquely determined under a dynamic panel fixed effects framework using firm-specific variables along with macroeconomic and financial development determinants of profitability. This relationship is estimated for a large and new data set of 12 industrial and emerging Asia-Pacific economies.
\end{abstract}

Keywords Firm, Size, Growth, Profitability, Panel fixed effects, Asia-Pacific

Paper type Research paper

(C) Inder Sekhar Yadav, Debasis Pahi and Rajesh Gangakhedkar. Published in European Journal of Management and Business Economics. Published by Emerald Publishing Limited. This article is published under the CreativeCommons Attribution (CC BY 4.0) licence. Anyone may reproduce, distribute, translate and createderivative works of this article (for both commercial and non-commercial purposes), subject to fullattribution to the original publication and authors. The full terms of this licence may be seen at http://creativecommons.org/licences/by/4.0/legalcode

Conflict of interest: On behalf of all authors, the corresponding author states that there is no conflict of interest. 
EJMBE 31,1

116

\section{Background}

The present work tries to empirically examine two traditional questions of business and industrial economics: first, what is the relationship between firm size and profitability? and second what is the association between firm growth and profitability? Both theoretical and empirical discussions have led to inconsistent and contradictory conclusions. A basic proposition of economic theory is that, under perfect competition, profit rates of all firms tend to be equal (Hall and Weiss, 1967). However, when imperfect markets are taken into consideration, the size of a firm becomes an important factor of producing profits. Accordingly, early theories of business economics have recognized the role of economies of scale (Alexander, 1949; Stekler, 1964; Hall and Weiss, 1967; Scherer, 1973) and other technical and economic efficiencies associated with larger business firms. For example, Baumol (1959) in his seminal work hypothesized a positive relationship between firm size and business profitability. Baumol argued that, "at least up to a point, increased money capital will not only increase the total profits of the firm, but because it puts the firm in a higher echelon of imperfectly competing capital groups, it may very well also increase its earnings per dollar of investment even in long-term". Accordingly, Baumol (1959) contended that large firms are capable of enhancing the investment opportunities, which bring larger profit rates, but the smaller firms cannot take them because of financial difficulties. Besides, large firms have an advantage over smaller firms as they can enter in varieties of product lines, which gives them the benefits of both the scale and the size. Consequently, the large firms are in a position to take full advantage of technical and pecuniary economies of scale in manufacturing, marketing, supervision and in raising capital. Hence, Baumol (1959) states his hypothesis on the firm size and profitability as, "other things being equal, the large firm can ordinarily obtain profits at least as large, and perhaps larger, than the smaller enterprise".

Contrary to Baumol's hypothesis, certain works on industrial theory and organization have also recognized limits to the growth of firms (Yadav et al., 2020) which may negatively impact their profitability. For example, earlier works of Robinson (1934), Coase (1937), Penrose (1955) and Williamson (1975) have all argued that firm growth breeds inefficiency and therefore, there are limits to growth. According to them, as firms grow larger and larger, diseconomies of scale may appear and a firm may reach a size at which the benefit from the last internalized transaction may be offset by management failure or some other internal or external factor. Also, according to them, large firms cannot undertake the options open to small firms as efficiently as the small firms undertake. Hence, profitability may decline with the growth of firms postulating a negative relationship between them.

Thus, contradictory theoretical arguments exist regarding the relationship between the firm size, growth and profitability. In this context, several empirical studies (discussed in next section) have revealed a mixed evidence. Additionally, many studies have also noted that other control factors like market structure, entry barriers and firm strategies may also determine the profitability of firms. Also, certain macroeconomic variables may affect the profits of firms from time to time. Thus, there is an interesting but inconclusive debate about this issue and therefore, it becomes important to empirically investigate the relationship between firm size, growth and profitability, particularly for emerging markets. Further, in context of selected emerging Asia-Pacific markets, the analysis of the relationship between the firm size, growth and profitability becomes important for the following economic implications: (1) industrial concentration: a positive relationship between average profitability and size would suggest that the degree of industrial concentration is likely to increase by large firms growing at a faster average rate than small firms (Whittington, 1980). Further, if the relationship between profitability and growth is positive, it will lead to higher growth rate, because higher profits provide both the means and better accessibility of money from retained earnings or from the capital market and the incentive for a higher rate of return from new investment (Whittington, 1980). (2) measure of risk: the variability of profitability 
through time, measures the firm risk (Whittington, 1980). Lower variability would imply that the average return had desirable risk characteristics, so that even if the average rate of profit did not vary with firm size, one would expect declining variability of profitability with respect to firm size to provide an incentive for relatively high growth of large firms (Whittington, 1980). (3) optimum size: if average profitability increases with size, then profitability is not constrained by size. In such a situation, it will be a positive inducement for the firms to grow more and more suggesting that there is no optimum size.

This study provides some important contributions to the existing empirical literature. First, the analysis of the relationship between the firm size, growth and profitability is uniquely determined under a dynamic panel fixed effects framework using firm-specific variables along with macroeconomic and financial development determinants of profitability. This relationship is estimated for a large and new data set of 12 industrial and emerging Asia-Pacific economies. The macroeconomic and financial development determinants along with size and growth variables have not been used before in a single framework. Second, the persistence of profits of firms is also investigated in a single dynamic panel framework which provides additional evidence on the convergence of profit rates across all firms in the long run. This further adds to the existing literature. Third, the interrelationship between firm size, growth and profitability is also examined for small, medium and large size companies classified based on three alternate measures such as total assets, net sales and market capitalization ratio of firms which further provides additional evidence based on different size classes using alternate size variables. Overall, this work contributes to better understanding of correlation between firm size, growth and profitability along with macroeconomic and financial development determinants for 12 cross countries which have important economic and firm level policy implications.

\section{Empirical literature [1]}

\subsection{Size and profitability}

Traditional research on determinants of profit rates, primarily focused on industry-level determinants of competition such as concentration, entry and exit barriers and economies of scale (Goddard et al., 2005). One such early work was by Bain in 1951 where he sought to test statistically, whether the profit rates of firms in American manufacturing industries of high seller concentration on average is larger than those firms in industries of lower concentration from 1936 through 1940. His statistical work suggested that the average after-tax return on equity of eight leading firm's concentration ratio was positive. Also, the study did not find any association of concentration to other potential determinants of profitability, nor were other such determinants significantly related to profit rates. More importantly, absolute size of firm as measured either by assets or by net worth did not appeared to be significantly related to profit rates. Later, Bain in 1956 maintained that actual or potential entry is an important determinant of performance of manufacturing firms in American industry. He hypothesized that, greater the structural barriers to competition from new sellers, farther will industry performance be from the competitive optimum.

However, as noted before, Baumol (1959) shifted the focus from concentration, entry and exit barriers to economies of scale and operational efficiencies associated with larger firm size. From time to time, empirical studies exploring the relationship between firm size and profitability have shown mixed evidence. For example, early empirical work of Stekler (1964) found that the variability of the profit rates of firms in a particular size class is inversely correlated with size for US manufacturing firms during 1947-1958. However, the empirical work of Hall and Weiss (1967) strongly contended that size does tend to result in high profit rates for 341 US largest industrial corporations during 1956-1962 supporting the Baumol's hypothesis. But again, Samuels and Smyth (1968) found that the profit rates and firm size are inversely related for a cross-section firms of United Kingdom during 1954-1963.

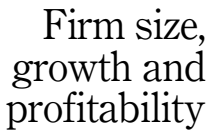


EJMBE 31,1

118
Likewise, Marcus (1969) tried to reevaluate the firm size and profitability hypothesis using new data within an improved analytical framework over three years: 1959-1960, 1960-1961, 1961-1962. His study found that the size of firm influences profitability in some, but not in all, industries; in 74 of 118 industries the null hypothesis that size has no effect on the rate of return could not be rejected at a five per cent probability level. Later, Shepherd (1972) found that size carries a negative coefficient with profitability, perhaps owing to X-inefficiency (the gap between actual and attainable profit of large absolute scale) for a panel of 231 large United States industrial firms during 1960-1969. Similarly, Caves and Porter (1977) and Porter (1979) held that the association between size and profit rates may vary across industries. Further, Whittington (1980) found that the average profitability of United Kingdom listed manufacturing firms during 1960-1974 was largely independent of firm size, and if such relationship exists, it tends to be negative. The study also observed that the interfirm dispersion of profitability tends to decline with firm size, although the relationship was not strong. Even, Amato and Wilder (1985) found no relationship between firm size and profit rate, using a data set which covers a wide range of firm sizes (largest 500 firms to a much larger range of firm sizes in the manufacturing sector) for the years 1966 and 1975.

Recent evidence on the relationship between firm size and profitability is also found to be mixed. For example, Amato and Amato (2004) argued that the typical firm size-profitability relationship established for manufacturing firms does not hold in retailing industries. Goddard et al. (2005) found a negative size-profitability relationship for manufacturing and service sector firms in Belgium, France, Italy and the UK, for the period 1993-2001. However, Gschwandtner (2005) noted that larger US firms tend to enjoy higher long-run profit rates. Subsequently, Lee (2009) found evidence for positive correlation between profitability and size for over 7,000 US publicly-held firms during the period 1987-2006.

\subsection{Growth and profitability}

The tangible effect of firm growth on profitability has also been found to be inconsistent in theories and empirical studies. Alchian (1950) argue that fitter firms realize positive profits as a result of which they grow and survive suggesting that profitability of firms reflect the degree of fitness and accordingly envisage that profitable firms will grow. Equally, Myers and Majluf (1984), argued that an increase in retained earnings leads to an increase in investment and consequently to further expansion. That is, profit is an important source of finance for expansion. However, the classical perspective argues that if firms have higher profitability they would grow to exploit further growth opportunities that are less profitable but still create additional profits (Jang and Park, 2011) suggesting the following: the profit rates converge to zero; high profit rates have a positive impact on growth rates until the profit rate reaches zero and firm growth has a negative influence on profit rates (Jang and Park, 2011). Likewise, the neoclassical perspective argues that firms first exploit most available profitable growth options before considering less profitable opportunities until the marginal profit from the last growth opportunity is equal to zero (Jang and Park, 2011). Thus, profitable firms first maximize their overall profits through most available profitable growth options but later experience a decrease in profit rates. Further, Kaldor (1966), Verdoorn (1949) asserted that growth increases productivity and in turn enhances productivity through increased profit rates. Therefore, the above arguments theoretically explain the interrelationship between growth and profitability of firms.

However, as noted before, empirical studies related to growth and profitability have found mixed evidence. For example, Capon et al. (1990) found that growth of the firm was related to high profitability, but this was not significant in some industries. Likewise, Chandler and Jansen (1992), Mendelson (2000) and Cowling (2004) found a significant positive correlation between firm's sales growth and profitability, whereas Markman and Gartner (2002) reported insignificant association between growth and profitability. Furthermore, Reid (1995) reported 
that growth had a negative effect on profitability for young micro-firms (less than ten employees) in Scotland during 1985-1988. As well, some of the recent studies such as Coad (2007), Coad (2010), Coad et al. (2011), show a positive influence of growth on profits while Jang and Park (2011) show a negative effect of growth on profits. Thus, overall evidence suggests that different studies have drawn different conclusions regarding the relationship between firm size, growth and profitability.

\section{Data and econometric model}

\subsection{The data and sample}

The sample consists of an unbalanced panel data for about 12,001 unique non-financial listed and active firms from 1995 to 2016 for 12 industrial and emerging Asia-Pacific [2] economies. The firm specific variables are collected from COMPUSTAT Global database. The firm year observations and average number of firms of selected Asia-Pacific economies included in the analysis is reported in Table 1.

3.1.1 Classification of small, medium and large firms. In addition, to examine the existence of significant differences between small sized, medium sized and large sized firms, the present study divides the full sample into small, medium and large size companies using three alternate measures viz., total assets (TA), net sales and market capitalization ratio (MCR) which is reported in Table 2. Companies whose total assets is less than or equal to $\$ 2955.75$ million are classified as small sized companies. Companies whose total assets range from $\$ 2955.76$ million to $\$ 38991$ million are classified as medium sized companies. Companies whose total assets are greater than $\$ 38991$ million are classified as large sized companies (Table 2). Accordingly, using this criterion of classification the sub sample had 39,318 firm

\begin{tabular}{lccr}
\hline Economy & Total firm-year observations & Average no. of firms & Percentage share (\%) \\
\hline China & 26,674 & 1905 & 26.721 \\
Hong-Kong & 1,170 & 66 & 0.930 \\
Indonesia & 1,092 & 42 & 0.590 \\
India & 15,993 & 1142 & 16.021 \\
Israel & 1,018 & 68 & 0.957 \\
Japan & 43,790 & 2255 & 31.624 \\
South Korea & 12,934 & 809 & 11.350 \\
Malaysia & 6,689 & 359 & 5.034 \\
Pakistan & 1,973 & 104 & 1.459 \\
Philippines & 722 & 39 & 0.551 \\
Singapore & 3,848 & 217 & 3.046 \\
Thailand & 2,275 & 123 & 1.718 \\
All & 118,178 & 7,130 & 100
\end{tabular}

Source(s): Authors' calculations based on COMPUSTAT Global Database
Firm size, growth and profitability

\begin{tabular}{lcccccc}
\hline Size/ & $\begin{array}{c}\text { TA } \\
\text { Measure }\end{array}$ & $\begin{array}{c}\text { Total no. of } \\
\text { (\$millions) }\end{array}$ & $\begin{array}{c}\text { Net sales } \\
\text { observation }\end{array}$ & $\begin{array}{c}\text { Total no. of } \\
\text { observation }\end{array}$ & MCR & $\begin{array}{c}\text { Total no. of } \\
\text { observation }\end{array}$ \\
\hline Small & $\leq 2955.75$ & 39,318 & $\leq 2295.1$ & 39,276 & $\leq 54$ & 41,195 \\
Medium & 2955.76 to & 39,410 & 2295.11 to & 39,451 & 54.00 to & 38,312 \\
Large & 38,991 & 37,052 & 36.56 & 38,671
\end{tabular}

Source(s): Authors' calculations based on COMPUSTAT Global Database 
EJMBE 31,1 year observations for small sized companies, 39,410 firm year observations for medium sized companies and 39,450 firm year observations for large sized companies (Table 2).

Similarly, companies whose net sales is less than or equal to $\$ 2295.10$ million are classified as small sized companies. Companies whose net sales range from $\$ 2295.11$ million to $\$ 37,052$ million are classified as medium sized companies. Companies whose net sales are greater than $\$ 37052$ million are classified as large sized companies (Table 2). Accordingly, using this criterion of classification the sub sample had 39,276 firm year observations for small sized companies, 39,451 firm year observations for medium sized companies and 39,451 firm year observations for large sized companies (Table 2). Finally, companies whose MCR is less than or equal to $54 \%$ are classified as small sized companies. Companies whose MCR range from 54.01 to $76.56 \%$ are classified as medium sized companies. Companies whose MCR is greater than $76.56 \%$ are classified as large sized companies (Table 2). Accordingly, using this criterion of classification the sub sample had 41,195 firm year observations for small sized companies, 38,312 firm year observations for medium sized companies and 38,671 firm year observations for large sized companies (Table 2).

\subsection{Measurement of variables [3]}

3.2.1 Profitability. (1) Return on assets (ROA): ROA is income before extraordinary items (Item G378), divided by the average of the most recent two years of assets-total (Item G107). This is then multiplied by 100 . Income before extraordinary items represents income after the deduction of all expenses, including allocations to untaxed balance sheet reserves (if applicable), income taxes, minority interest, and net items, but before extraordinary items and provisions for dividends while assets-total represents the sum of current assets, net property, plant, and equipment, and other noncurrent assets. (2) Return on equity (ROE): ROE of firms is measured as income before extraordinary items-common (Item G378) which is defined as income before extraordinary items and discontinued operations less preferred dividend requirements, but before adding savings due to common stock equivalents divided by common equity (Item G277 which is defined as the common shareholders' interest in the company.

3.2.2 Firm specific determinants of profitability. (1) Firm size (S): Size of the firm is measured using two alternate variables viz., total assets and net sales. Total Assets (TA) (Item G107) represents current assets plus net property, plant, and equipment plus other noncurrent assets (including intangible assets, deferred charges, and investments and advances). (2) Leverage (LEV): Leverage of firms is measured as a ratio of total debt to equity (DER). This leverage ratio measures the firm's total capital structure and is defined as the sum of long-term debt (Item G135) and debt in current liabilities (Item G132), divided by common equity-total (Item G227). Debt in current liabilities represents the total amount of short-term notes and the current portion of long-term debt that is due in one year. It includes several items like bank acceptances and overdrafts, brokerage companies' drafts payable commercial paper, construction loans, current portion of long-term debt, debt in default, debt due on demand, due to factor if "interest bearing", installments on a loan, line of credit, loans payable to officers of the company, loans payable to parents, and consolidated or unconsolidated subsidiaries, loans payable to stockholders, notes payable to banks and others, notes payable that are included in accounts payable, unless specifically trade notes payable, sinking fund payments. This item may include mortgage indebtedness for banks (included in current liabilities - other, if identifiable). The long-term debt total of a firm refers to the debt obligations due more than one year from the company's balance sheet date or due after the current operating cycle. It includes debt obligations like bonds, loans, mortgages, advances from other firms, installment obligations, line of credit (when reclassified as a noncurrent liability), loans on insurance policies and long-term lease obligations (capitalized lease obligations). The common equity-total represent the common shareholders' interest in the 
company. It includes common stock (including effects of common treasury stock), capital surplus, retained earnings, and treasury stock adjustments for both common and nonredeemable preferred stock. (3) Competition (COMP): Competition is measured by the net sales (Item G608) based Herfindahl-Hirschman Index (HHI). HHI is measured as the total of the squared market share of all firms in the industry " $k$ " in year " $l$ ". To define industries, COMPUSTAT four-digit Standard Industry Classification (SIC) codes are used. Higher HHI implies high industry concentration and low competition, whereas lower $\mathrm{HHI}$ implies less industry concentration and more competition. Firms in the highest HHI industries are noncompetitive firms, and firms in the lowest HHI industries are competitive firms. (4) Tangibility (TANG): Tangibility is measured as the ratio of net property, plant, and equipment (Item G85) divided by assets-total (Item G107). Net property, plant, and equipment represents the net cost or valuation of tangible fixed property used in the production of revenue while assets-total represents the sum of current assets, net property, plant, and equipment, and other noncurrent assets.

3.2.3 Macroeconomic [4] determinants of profitability. (1) GDP growth (annual \%) ( $\Delta \mathrm{GDP})$ is the annual percentage growth rate of GDP at market prices based on constant local currency. GDP is the sum of gross value added by all resident producers in the economy plus any product taxes and minus any subsidies not included in the value of the products. It is calculated without making deductions for depreciation of fabricated assets or for depletion and degradation of natural resources. (2) Market capitalization ratio (MCR) an indicator of the size of the stock market is measured as the value of listed shares divided by GDP.

\subsection{Modeling the determinants of profitability}

The following is the specified econometric model:

$$
\pi_{i t}=\alpha_{i}+\pi_{i t-1}+S_{i t}+\Delta S_{i t}+\sum_{j=1}^{k} \beta_{j} X_{j, i, t}+\delta_{t}+\varepsilon_{i t} \ldots
$$

where $\pi_{i t}$ is the profit variable for firm $i$ in period $t, S_{i t}$ is the natural log of size variable for firm $i$ in period $t, \Delta S_{i t}$ is the growth rate of firm measured as the difference between $S_{i t}$ and $S_{i t-1}$, $X_{j, i, t-1}$ is the vector of firm-specific and macroeconomic independent variables, $\alpha_{i}$ and $\delta_{t}$ are individual and time effects, respectively. $\varepsilon_{i t}$ is the disturbance term assumed to be normal, independent and identically distributed (IID) with $\mathrm{E}\left(\varepsilon_{i t}\right)=0$ and $\operatorname{var}\left(\varepsilon_{i t}\right)=\sigma_{\varepsilon}^{2}>0$.

The dynamic specification of Eqn (1) also allows to investigate the "persistence of profits" of firms' overtime. The dynamic panel regression is estimated using the fixed effects (FE) approach and the random effects approach using OLS. For choosing between fixed effects and the random effects model the assumption one makes about the likely correlation between the cross-section specific error component $\left(\varepsilon_{i}\right)$ and the $X$ regressors is important. If it is assumed that error component and the $X$ 's are uncorrelated, random effects model may be appropriate. However, if $\varepsilon_{i}$ and the $X$ 's are correlated, fixed effects models may be appropriate. The formal test developed by Hausman (1978) is used to choose between fixed effects and the random effects approach. In order to reduce the effects of heteroskedasticity on inferences a heteroskedasticity-consistent standard error estimator of OLS parameter estimates (White, 1980; MacKinnon and White, 1985; Long and Ervin, 2000) is employed. This approach employs an alternative method of estimating the standard errors that does not assume homoscedasticity.

\section{Empirical results and discussion}

\subsection{Summary statistics and correlation analysis}

Table 3 displays summary statistics of the selected variables. The mean profit rate (ROA) [5] is about $4.40 \%$ for the aggregate sample. All the selected economies recorded a positive mean

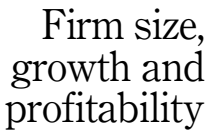

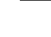




\begin{tabular}{l} 
EJMBE \\
31,1 \\
$\mathbf{1 2 2}$ \\
\hline
\end{tabular}

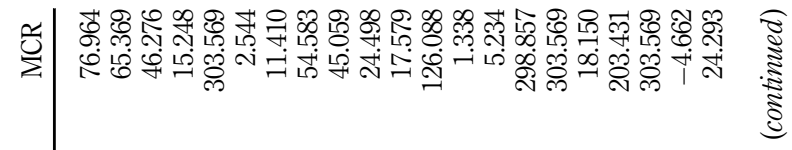

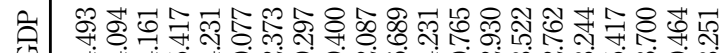
+ + +

भ \& เि

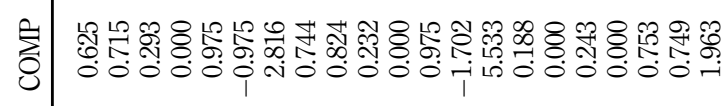

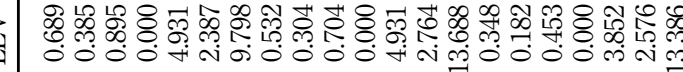

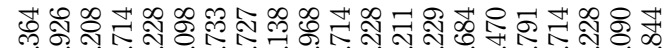

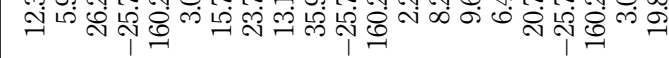

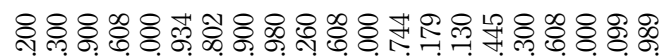

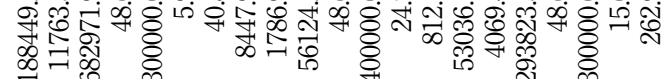

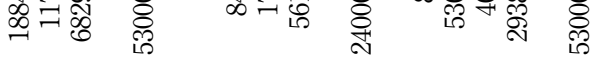

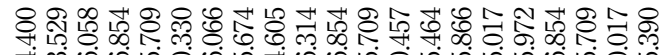
+ कं

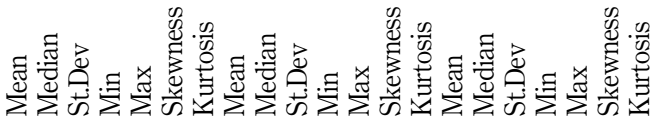

Table 3.

Sample summary statistics 


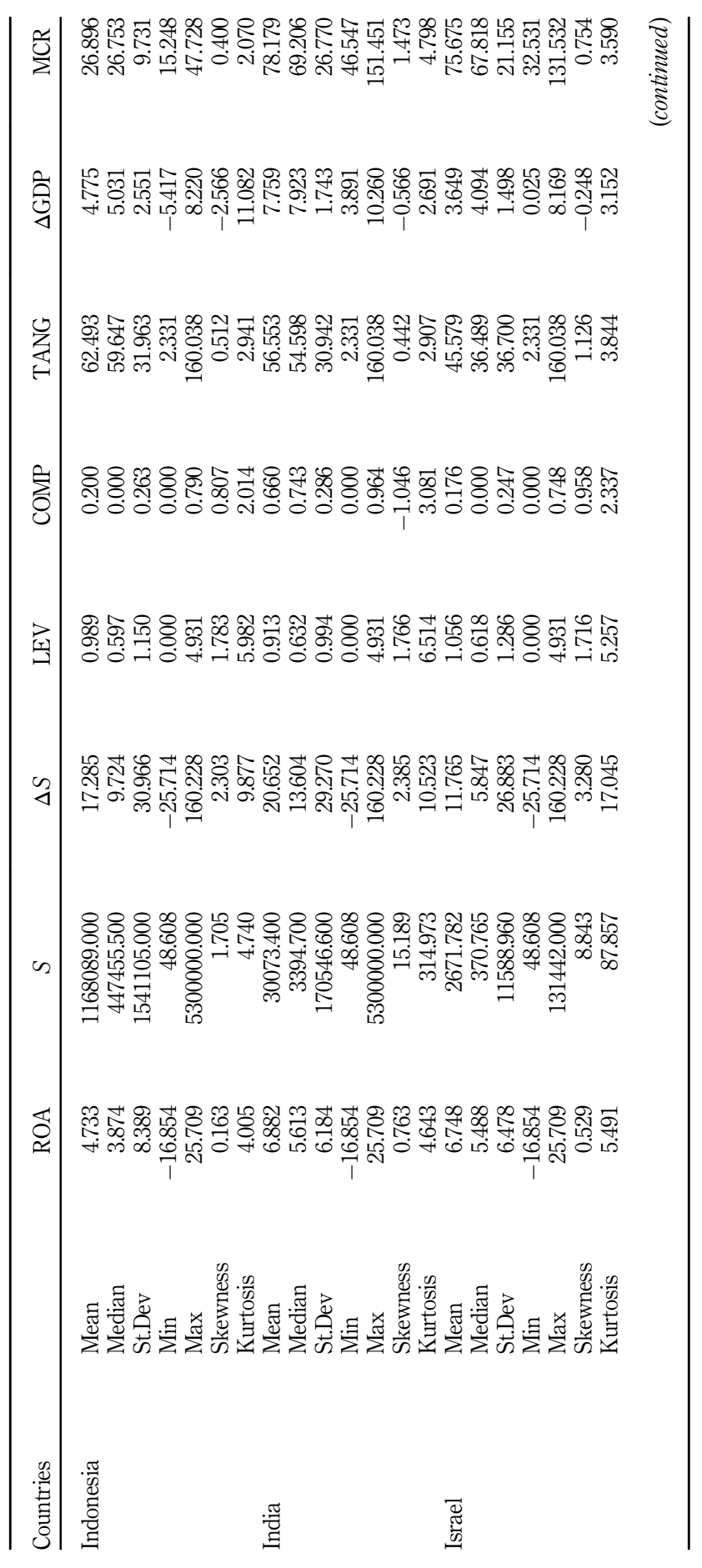

Firm size, growth and profitability

123

Table 3. 


\begin{tabular}{l} 
EJMBE \\
31,1 \\
$\mathbf{1 2 4}$ \\
\hline
\end{tabular}

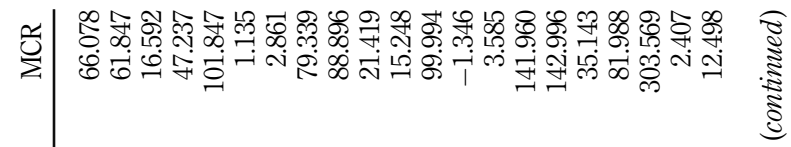

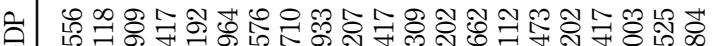

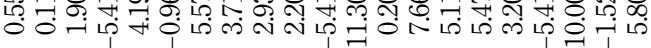

ப) 굴 ๙

过

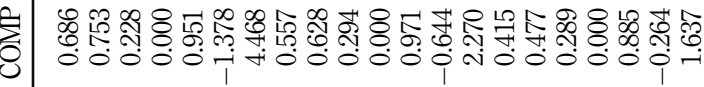

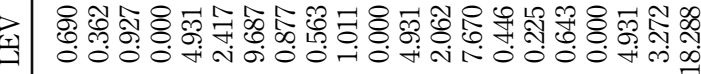

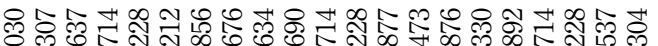

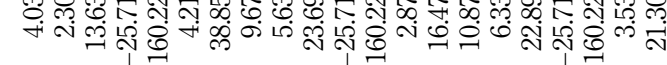

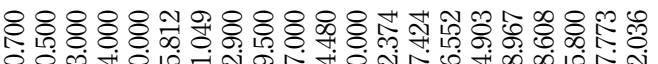

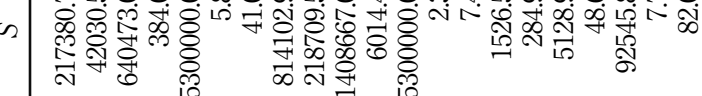

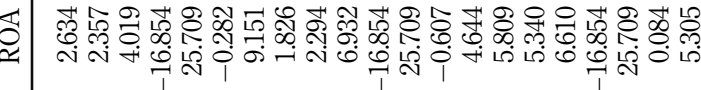

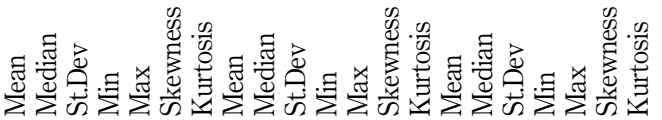

Table 3. 


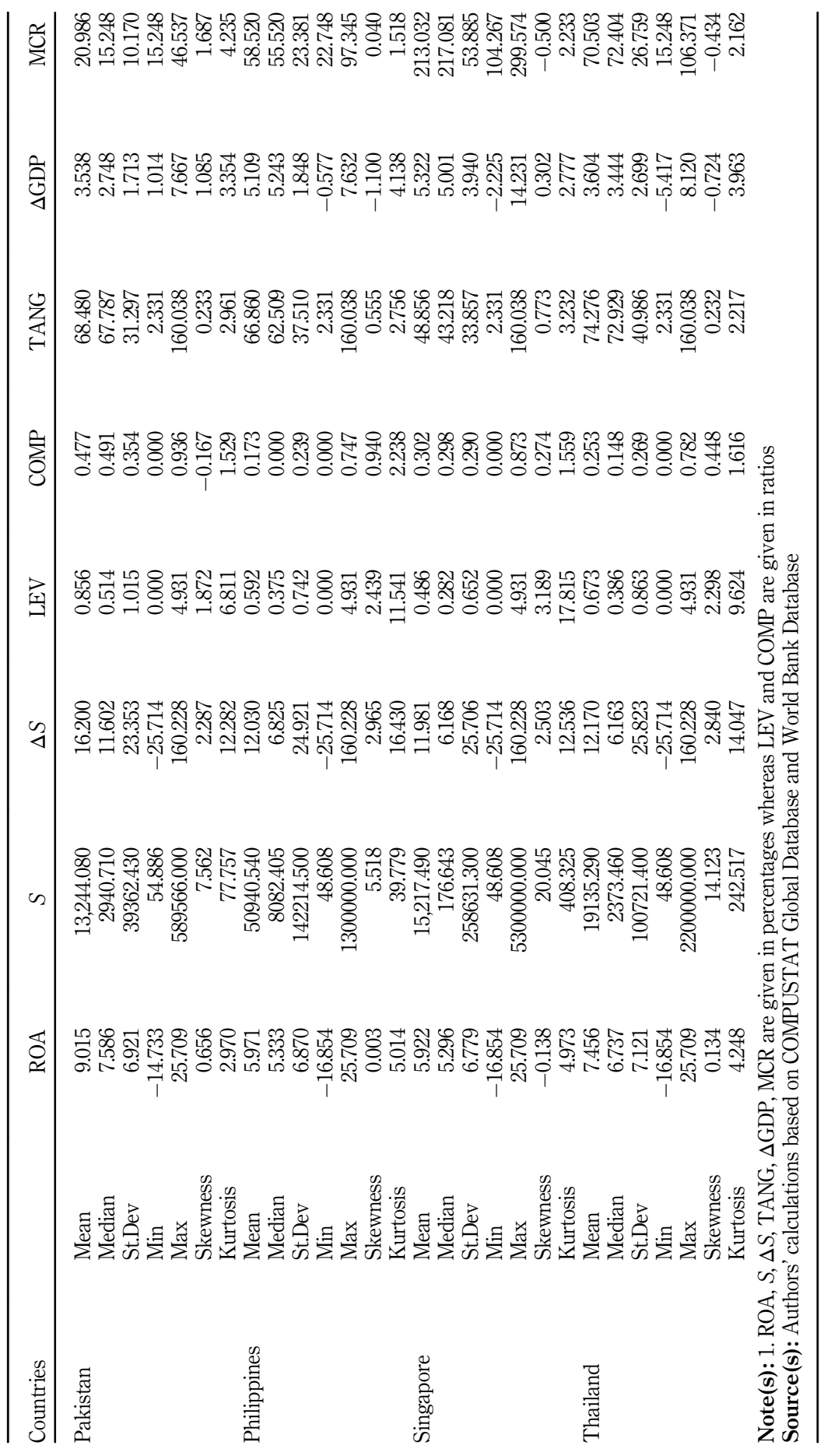

Firm size, growth and profitability

Table 3. 
EJMBE 31,1

126

profit rates which ranged between $9.02 \%$ (Pakistan) and 1.83\% (South Korea). For economies such as China (5.67\%), Hong Kong (5.87\%), India (6.88\%), Israel (6.75\%) Malaysia $(5.81 \%)$, Philippines $(5.97 \%)$, Singapore $(5.92 \%)$ and Thailand $(7.46 \%)$ the mean profit rates were recorded above the mean profit rate of the aggregate sample reflecting greater buoyancy for these economies. However, for countries such as Indonesia (4.73\%), Japan (2.63\%) and South Korea $(1.83 \%)$ the mean profit rates were recorded below the mean profit rate of the aggregate sample. Firm size, as measured by total assets, varied widely across the selected economies (Table 3). On average, the sample firms have about $\$ 188449.200$ million [ $\$ 11763.300$ million median] in assets (S). The annual average growth of assets $(\Delta S)$ is about $12.36 \%(5.93 \%$ Median), ranging from $23.73 \%$ (China) to $4.03 \%$ (Japan). Indonesia (17.29\%), India $(20.65 \%)$ and Pakistan $(16.20 \%$ ) have experienced growth rates above the sample average.

The mean leverage ratio (LEV) for the sample is about $68.9 \%$. The economies which have leverage ratio above the mean leverage ratio of full sample are Indonesia $(98.9 \%)$, India (91.3\%), Israel (105.6\%), Japan (69.0\%), South Korea (87.7\%) and Pakistan (85.6\%). As noted before, market competitiveness is normally considered to be an outcome of market concentration. The mean $\mathrm{HHI}$ ratio is about $62.5 \%$ for the full sample. The concentration ratio (COMP) of industries in China $(74.4 \%)$, India $(66.0 \%)$ and Japan $(68.6 \%)$ is higher than the mean concentration ratio of full sample. The industries in Israel $(17.6 \%)$ and Philippines $(17.3 \%)$ are least concentrated. For the full sample the mean of tangibility of assets (TANG) is about $57.41 \%$, ranging from $74.28 \%$ (Thailand) to $44.85 \%$ (China). The mean market capitalization ratio (MCR) is nearly $76.96 \%$ for the aggregate sample, ranging from 298.86 (Hong Kong) to $20.99 \%$ (Pakistan). The annual mean growth of GDP ( $\triangle$ GDP) is nearly $4.49 \%$ for the selected economies, ranging from $0.56 \%$ (Japan) to 9.30 (China).

The pairwise correlation among the selected variables is displayed in Table 4. It is observed that coefficient of correlation between the size (S) variable and profitability (ROA) variable is negative and significant positing a negative relationship between the profitability and firm size for the selected Asia-Pacific economies. However, the coefficient of correlation between the firm growth $(\Delta S)$ variable and profitability is observed to be negative and significant positing a positive relationship between the two. The other chosen firm specific variables such as leverage (LEV), tangibility (TANG) and competition (COMP) is observed to be negatively and significantly correlated with the firm's profitability. The annual growth of $\mathrm{GDP}(\triangle \mathrm{GDP})$ and MCR is observed to be positively correlated with the profitability of selected firms during the study period.

\subsection{Graphical analysis}

Before estimating the econometric models, the visual fundamental relationship between profit rates, firm size and growth is examined graphically using the non-parametric scatter

\begin{tabular}{|c|c|c|c|c|c|c|c|c|}
\hline Variables & (1) & (2) & (3) & (4) & (5) & (6) & (7) & (8) \\
\hline (1) $\mathrm{ROA}$ & 1 & & & & & & & \\
\hline (2) $S$ & $-0.257^{*}$ & 1 & & & & & & \\
\hline (3) $\Delta S$ & $0.269 *$ & $-0.153 *$ & 1 & & & & & \\
\hline (4) LEV & $-0.313^{*}$ & $0.188^{*}$ & $0.014^{*}$ & 1 & & & & \\
\hline (5) COMP & $-0.034^{*}$ & $0.050 *$ & $0.027 *$ & $-0.016^{*}$ & 1 & & & \\
\hline (6) TANG & $-0.135^{*}$ & $0.168 *$ & $-0.211^{*}$ & $0.153^{*}$ & 0.002 & 1 & & \\
\hline (7) $\Delta \mathrm{GDP}$ & $0.225^{*}$ & $-0.474 *$ & $0.299 *$ & -0.002 & $0.037^{*}$ & $-0.157^{*}$ & 1 & \\
\hline (8) MCR & $0.073^{*}$ & $-0.234^{*}$ & $0.010^{*}$ & $-0.066^{*}$ & $-0.245^{*}$ & $-0.052^{*}$ & $0.057^{*}$ & 1 \\
\hline VIF & 1.42 & 1.39 & 1.14 & 1.13 & 1.10 & 1.07 & 1.07 & 1.1 \\
\hline
\end{tabular}

Table 4.

Pairwise correlation among the selected variables
Note(s): 1 . *shows significance at the 0.05 level

Source(s): Authors' calculations based on COMPUSTAT Global Database and World Bank Database 
plots presented in Figures $1-4$. The scatter plots for profitability ( $Y$-axis) and firm size $(X$ axis) for aggregate sample as well as for respective economies though initially have a cloud shape and are a bit scattered horizontally (suggesting no relationship) but are eventually observed to decline overtime as the size of the firm increases depicting a negative relationship between profitability and firm size (Figures 1 and 2). However, the scatter plots for profitability ( $Y$-axis) and firm growth ( $X$-axis) for aggregate sample as well as for respective economies also though initially have a cloud shape and are bit scattered horizontally but are eventually observed to increase as the growth of the firm increases depicting a positive correlation between profitability and firm growth (Figures 3 and 4).

\subsection{Econometric analysis}

For the full sample and country-wise, panel data FE regression estimates with unobserved firm-specific or individual effects estimated using Eqn (1) is reported in Table 5. It is important to observe that the FE estimates given by Eqn (1) assume that the slope coefficients of the regressors do not vary across individuals or over time although the intercept may differ across firms but each firm's intercept does not vary over time, that is, it is time-invariant. However, the estimates for the firm-specific intercepts are not reported to save space. In addition to the lagged dependent variable $\left(\mathrm{ROA}_{i t-1}\right)$, Eqn (1) includes 07 [firm-specific firm size (S); firm growth $(\Delta \mathrm{S})$; leverage (LEV); competition (COMP) and tangibility (TANG) and macroeconomic-GDP growth $(\Delta \mathrm{GDP})$; and market capitalization ratio (MCR)] independent determinants of profitability discussed in Section 3.

The coefficient of lagged profit rate $\left(\mathrm{ROA}_{i t-1}\right)$ in Table 5 is found to be positive and statistically significant for the full sample as well as across the individual economies during the estimation period. The estimate of lagged coefficient for the full sample is around 0.278 suggesting that if the past profit rate goes up by one percentage point, holding other explanatory variables constant, the current ROA will increase by $0.278 \%$ points reflecting a modest level of "persistence of profits" over time. The dynamics of firm's profitability is being specified as a first order autoregressive process after the seminal contribution of Mueller (1986) where Geroski (1990) provided a theoretical explanation for such an empirical

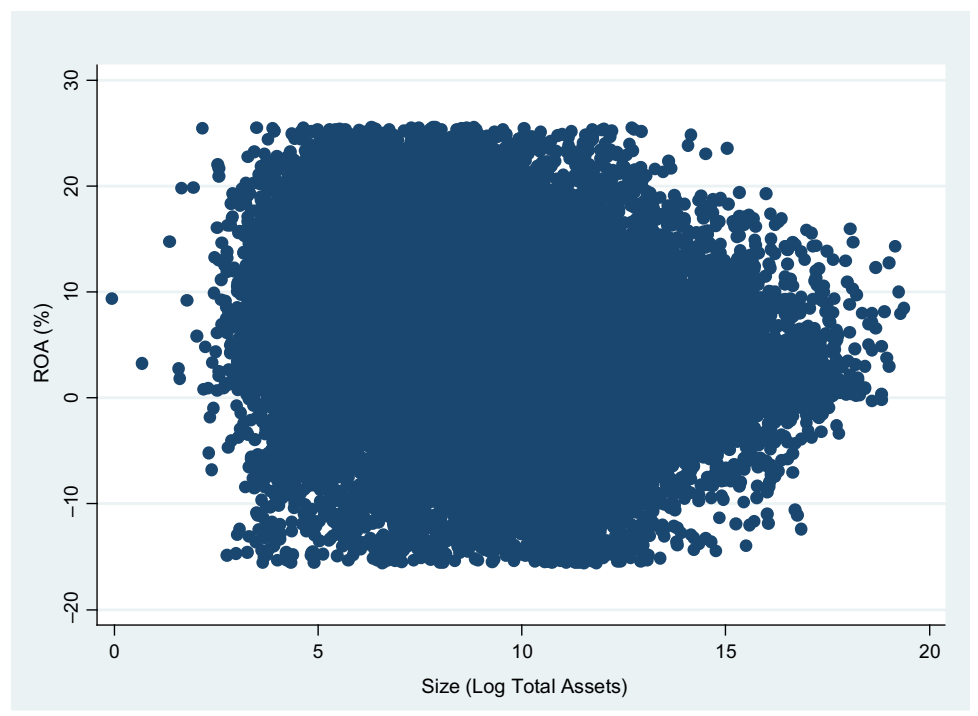

Figure 1.

Firm size and profitablility. Aggregate sample 
EJMBE

31,1

Figure 2.

Firm size and

profitablility.

Country-Wise 


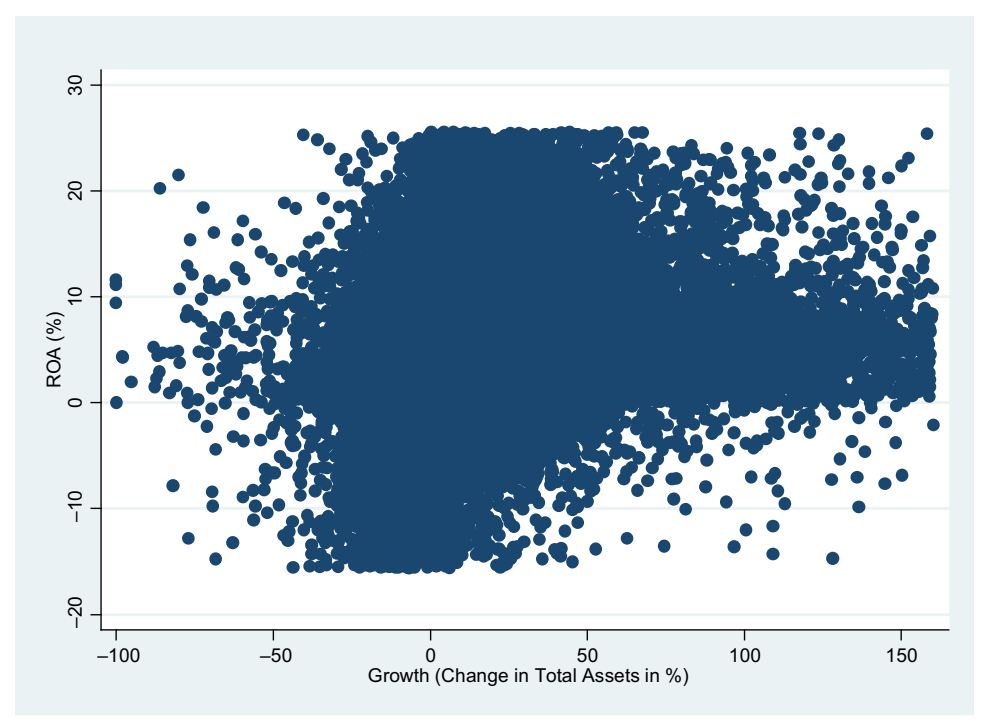

Firm size, growth and profitability

measurement, based on the assumption that profits depend on the threat of entry in the market, which in turn depends on past profits (Gschwandtner and Cuaresma, 2013). The contention behind "persistence of profits" is that for reasons like entry and exit barriers, first mover advantages or external shocks, firms might earn profits that are substantially above or below the norm over longer time periods (Gschwandtner and Cuaresma, 2013). The estimates of profitability persistence for full sample and across individual economies in present work is higher than the estimates of Mueller's (1990) and Lee (2009) but lower than Gschwandtner and Cuaresma's (2013) finding for profit data for US firms, spanning data for more than 150 firms over a period of 50 years. However, persistence of profits for economies such as Indonesia $(0.108)$ and South Korea $(0.142)$ is very negligible compared to other selected economies (Table 5).

The first main firm specific absolute firm size variable is estimated to be negative for full sample as well as across all the individual cross-sections indicating that firm size and profitability are negatively correlated during the sample period. However, the estimated size coefficient is significant for cross-sections such as China, India, Israel and Thailand whereas for rest of the selected cross-sections, the size variable is found to be irrelevant. This evidence does not lend support to conventional wisdom of positive firm size-profit relationship as postulated by Baumol (1959). The second important firm specific firm growth variable is estimated to be positive for full sample as well as across all the individual cross-sections indicating that firm growth and profitability are positively related during the sample period (Table 5). However, the estimated growth coefficient is insignificant for economic units such as China, Israel, Pakistan and Thailand whereas for rest of the selected economic units the growth coefficient is found to be relevant (Table 5). The estimates for the firm size and growth variables together suggest that initially profitability increases with the growth of the firm. But eventually, overtime, gains in profitability reduces for larger firms (larger size firms tend to experience lower profitability) apparently lending support to the arguments of Robinson (1934), Coase (1937), Penrose (1955) and Williamson (1975) that large size breeds inefficiency. This unique results corroborates the results obtained from the earlier graphical analysis.

Gale (1972) used leverage to measure risk. A priori, the relationship between leverage and rate of return may not be determinate [6] (Hurdle, 1974). Works of Stigler (1963), Scherer 
EJMBE

31,1
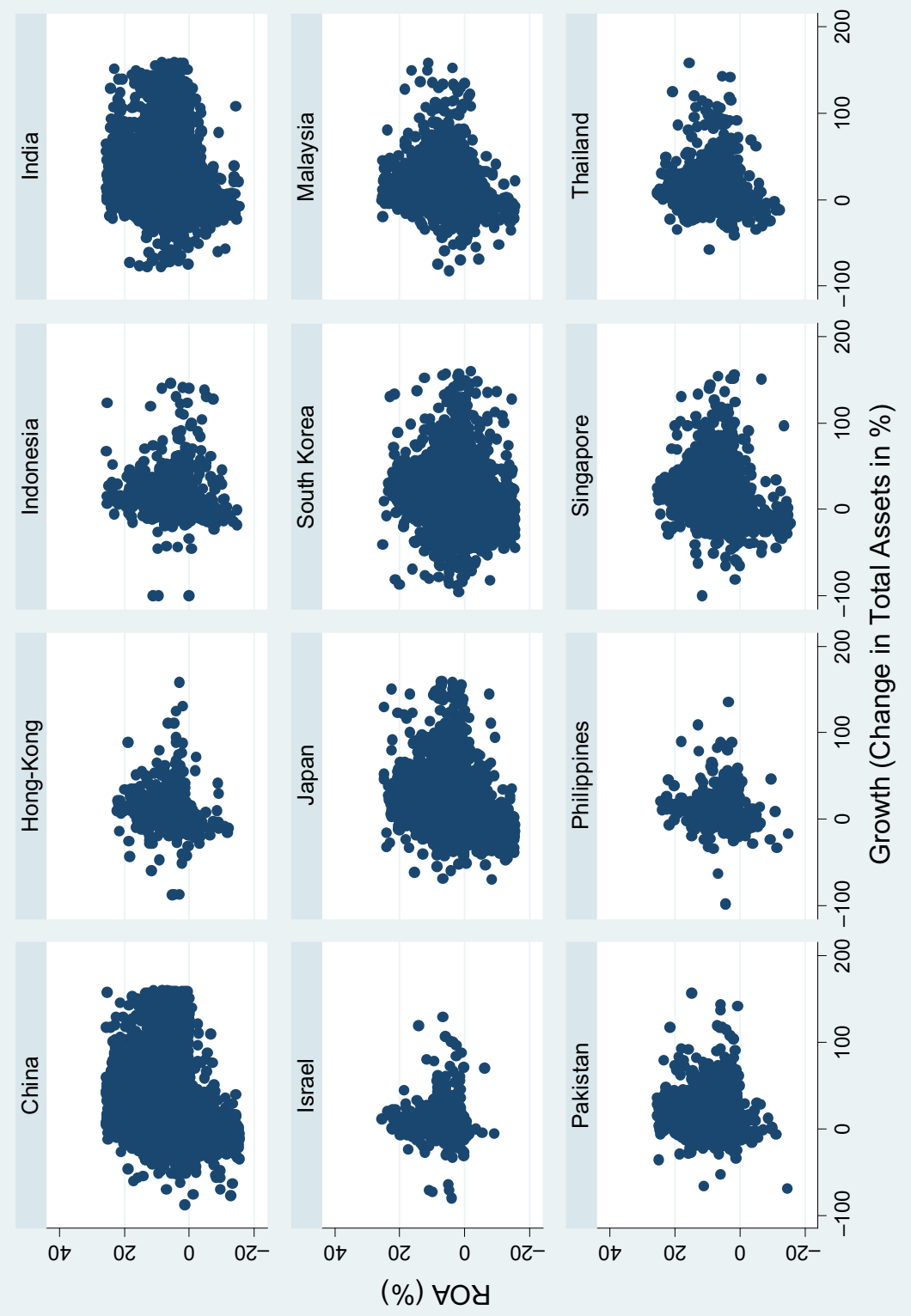

Figure 4.

Firm growth and profitablility.

Country-Wise 
Table 5.

Panel FE Estimates: Firm size, growth and profitability (All and 
EJMBE 31,1
(1970) and Jean (1970) have suggested that leverage may have an independent influence on profit rates of firms. According to Fazzari et al. (1988) and Stulz (1990) highly levered firms tend to be at greater risk of being unable to meet interest and debt repayment commitments. Since large amounts of leverage imply high risks, one would expect a negative relationship between profitability and leverage of firms (Hall and Weiss, 1967). Unanimously, the estimated FE coefficient of leverage (LEV) is found to be negative and statistically significant for the full sample as well as across all the selected economies suggesting that leverage is negatively related with profitability of selected firms (Table 5) supporting the arguments of Hall and Weiss (1967), Fazzari et al. (1988) and Stulz (1990). This evidence is consistent with a recent study of Goddard et al. (2005) for manufacturing and service sector firms in Belgium, France, Italy and the UK, during 1993-2001.

The estimated coefficient of competition (COMP) is found to be positive for the full sample as well as across the economic units. The positive correlation between profitability and industry concentration (HHI) suggests that as industry concentration (competition) increases (decreases), the firm's profitability increases as higher HHI implies high industry concentration and low competition, whereas lower HHI implies less industry concentration and more competition. Firms in the highest HHI industries are non-competitive firms, and firms in the lowest $\mathrm{HHI}$ industries are competitive firms. This finding is consistent with Bain's (1951) and numerous other works. However, the estimated coefficient of COMP is found to be significant for full sample and only for economies such as Hong-Kong, Malaysia and Pakistan.

One of the resource-based view is that management practices and organizational structures represent the main source of differences in performances between companies (Goddard et al., 2005; Gschwandtner and Cuaresma, 2013). Tangible internal resources like financial and physical factors of production, as well as, intangible internal resources as technology, management skills, quality reputation, and customer loyalty, reflect the main abilities of the firm that can lead to sustained profitability (Lippman and Rumelt, 1982; Werenfelt, 1984; Prahalad and Hamel, 1990; Mahoney and Pandian, 1992; Brush et al., 1999 Barney, 2001; Bowman and Helfat, 2001; Winter, 2003; Goddard et al., 2005; Gschwandtner and Cuaresma, 2013). Some of the existing studies such as Griliches and Lichtenberg (1984) for USA; Pusher (1995) for Japan; Deloof (2003) for Belgium; Smith et al. (2004) for Denmark; Nucci et al. (2005) for Italy and Serrasqueiro and Nunes (2008) for Portuguese have observed a negative relationship between the level of tangible assets and firm's performance. In a recent study, Kamasak (2017) reported that intangible resources contributed more greatly to Turkish firm performance compared to tangible resources. Accordingly, majority of these studies have reported a positive relationship between the level of intangible assets and company's performance. This finding suggests that firms with lower levels of tangible assets (or greater percentage of intangible assets in total assets) are more likely to innovate, which in turn contributes to higher levels of performance (Serrasqueiro and Nunes, 2008).

The FE estimates of asset tangibility (TANG) in the present analysis, is consistently significant and negative across all the economies as well as for the full sample. This finding indicate that that a lower level of tangible assets and greater tendency to innovate may contribute to increased levels of profitability for Asia-Pacific firms.

The estimated coefficient of regressor GDP growth $(\Delta \mathrm{GDP})$ reflecting the general macroeconomic condition is found to be positive and significant for full sample suggesting that profit rates are associated with the business cycle. The same is true for economies such as China, India, Israel and Japan. This finding is consistent with the findings of Domowitz et al. (1986) and inconsistent with findings of Lee (2009) for over 7,000 US publicly-held firms during the period 1987-2006 estimated using dynamic panel data model. However, the estimated coefficient of $\Delta$ GDP reported in Table 5 though found to be positive across all the individual economics is observed to insignificant for majority of the sample countries such as 
Hong-Kong, Indonesia, South Korea, Malaysia, Pakistan, Philippines, Singapore and Thailand consistent with findings of Lee (2009) and inconsistent with findings of Domowitz et al. (1986). For these sample economies, it seems that profit rates are not associated with the business cycle.

Stock market development plays an important role in mitigating the agency problem that may arise between various stakeholders of a corporate firm (Yadav et al., 2019). Stock markets not only provide entrepreneurs with liquidity but also provide with opportunities to diversify their portfolios (Demirguc-Kunt and Maksimovic, 1996). Based on literature, market capitalization ratio (MCR) is employed to measure the extent of development of stock market. The assertion behind this measure is that overall market size is positively correlated with the ability to mobilize capital and diversify risk on an economy wide basis (Agarwal and Mohtadi, 2004). Therefore, the performance of listed firms is expected to improve. The FE estimates of MCR in Table 5 is found to be having expected positive sign for the full sample as well as across individual economies. For the full sample the estimated MCR coefficient is meaningful whereas for economies such as Indonesia, India, Pakistan, Philippines and Thailand it is not meaningful. The adjusted $R^{2}$ from Table 5 indicates that the selected firmspecific and macroeconomic variables explain on average about $28 \%$ of profitability variations requiring much to be done in order to better understand the determining factors behind profitability of firms.

\subsection{Small, medium and large company analysis}

The panel FE estimates of firm size, growth and profitability across small, medium and large size companies is reported in Table 6. The sub sample analysis of firm size, growth and profitability across small, medium and large sized firms also consistently (classified based on total assets, net sales and MCR of firms) indicate that profitability decreases with increase in firm size whereas profit rate increases with growth of the firm. Other selected firm-specific and macroeconomic variables employed in the econometric analysis reveal similar results of full sample across small, medium and large size firms.

\section{Summary}

This study examined the correlation between firm size, growth and profitability along with other firm-specific and macroeconomic determinants of profitability using panel dynamic fixed effects model for nearly 12,001 unique non-financial listed and active firms from 1995 to 2016 for 12 industrial and emerging Asia-Pacific economies. The dynamic specification also allows to investigate the persistence of profits of firms. This interrelationship was also examined for small, medium and large size companies classified based on three alternate measures such as total assets, net sales and MCR of firms. The firm specific variables included along with firm size and growth variables are leverage, competition and tangibility whereas the macroeconomic determinants of profitability variables were GDP growth and MCR representing the stock market development.

The "persistence of profits" coefficient was found to be positive and statistically significant for the full sample as well as across the individual economies. However, the size of coefficient reflected a modest level of "persistence of profits" over time. Particularly, for Indonesia and South Korea, persistence of profits was very negligible compared to other selected Asia-Pacific economies.

Rejecting the traditional convention of positive firm size-profit relationship, econometric evidence in the present work suggested that the firm size variable had a negative sign for full sample as well as across all the individual cross-sections. This evidence indicates that firm size and profitability are negatively correlated during the sample period. Particularly, the size

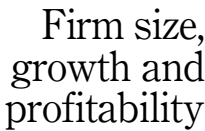

133 
EJMBE
31,1

\section{4}

Table 6.

Panel FE Estimates: Firm size, growth and profitability (small, medium and large companies)

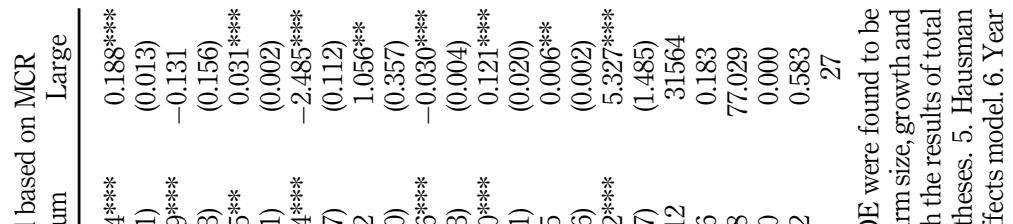

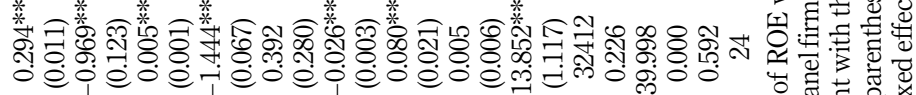
责

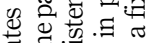

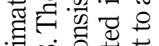

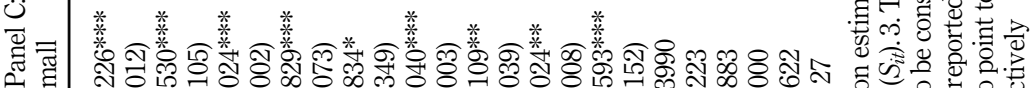
৩ * * * * * *

党: 范

ร

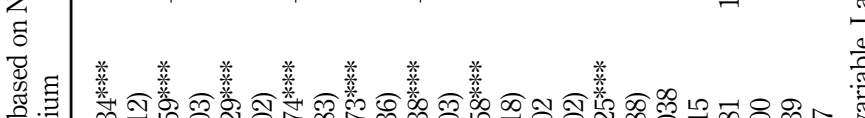
要远

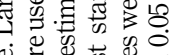

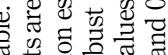

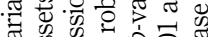

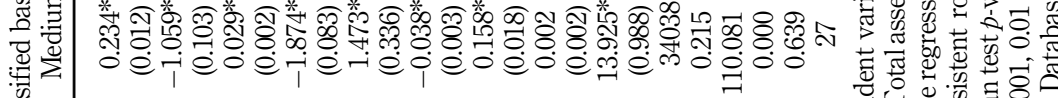
量

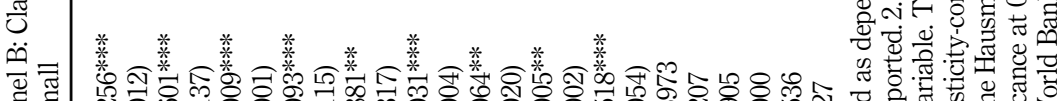

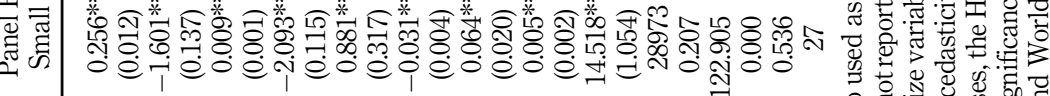

茪 की

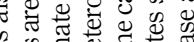

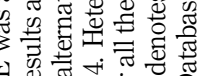
击 䓪 亏

艺 $*$ * * * * * * * * * * * * * * * *

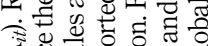

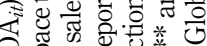

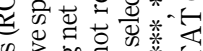

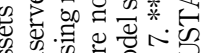

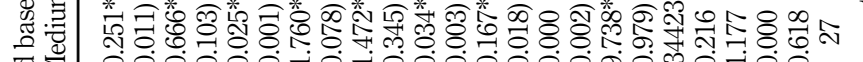
¿ 窇 ○े ธี

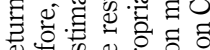

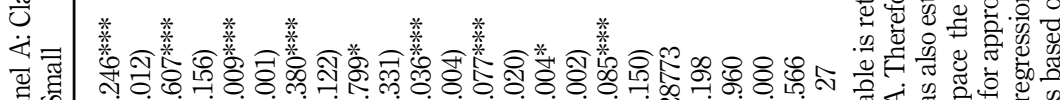
ฮี่

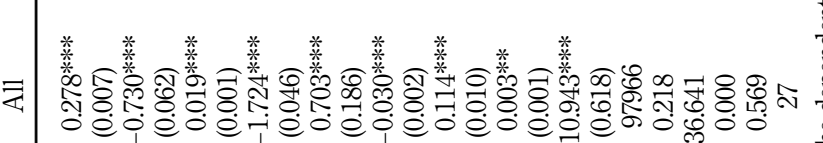

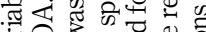

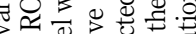

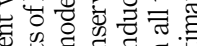
至 00.0

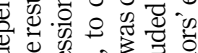
Q

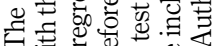

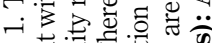

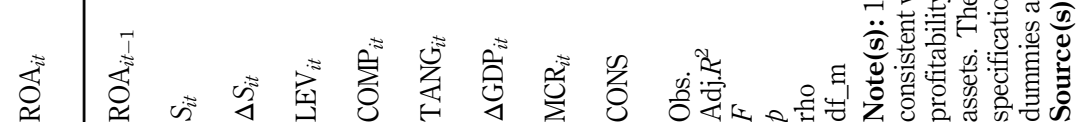


coefficient was significant for China, India, Israel and Thailand whereas for rest of the selected Asia-Pacific economies it was insignificant. The coefficient of firm growth was found to be positive for full sample as well as across all the individual cross-sections indicating that firm growth and profitability are positively related during the sample period. But the estimated growth coefficient was insignificant for China, Israel, Pakistan and Thailand. The negative size-profit and positive growth-profit relationship together suggest that initially profitability increases with the growth of the firm. But eventually, overtime, gains in profit rates reduces for larger firms (larger size firms tend to experience lower profitability) apparently indicting that large size breeds inefficiency.

Unanimously, the estimated FE coefficient of leverage was negative and statistically significant for the full sample as well as across all the selected economies suggesting that leverage is negatively related with profitability of selected firms. The estimated coefficient of competition was found to be positive for the full sample as well as across the selected AsiaPacific economies suggesting that as industry concentration increases, the firm's profitability increases. This relationship was significant only for economies such as Hong-Kong, Malaysia and Pakistan. The coefficient of asset tangibility was consistently significant and negative across all the economies as well as for the full sample indicating that a lower level of tangible assets and greater tendency to innovate may contribute to increased levels of profitability for Asia-Pacific firms.

The business cycle variable, GDP growth was positive and significant for full sample and for economies such as China, India, Israel and Japan suggesting that profit rates are associated with the business cycle. The stock market development variable, MCR was positive for the full sample as well as across individual economies. For the full sample the estimated MCR coefficient was meaningful whereas for economies such as Indonesia, India, Pakistan, Philippines and Thailand it was not meaningful. The panel FE estimates of firm size, growth and profitability across small, medium and large size companies indicated that profitability decreases with increase in firm size whereas profit rate increases with growth of the firm. Other selected firm-specific and macroeconomic variables employed in the econometric analysis revealed similar results of full sample across small, medium and large size firms.

\section{Policy implications}

This paper has some important economic and managerial implications on issues such as correlation between size, growth and profitability, and risk of firms for Asia-Pacific emerging markets. The negative size-profit and positive growth-profit results together suggest that initially profits increase with the growth of the firm. However, overtime, gains in profit rates reduce for larger firms indicting that large size breeds inefficiency suggesting that limits to growth is a dominant characteristic of industrial dynamics and therefore, firms have optimum size. Since profitability is constrained by size, growing firms eventually might experience lower profits implying that if firms focus only on growth, their long-run profits could be endangered. Consequently, growth oriented strategies alone may not be appropriate and desirable for the firm's long-run profitability. Along with growth oriented strategies managers may also focus and understand what breeds inefficiency for a large growing firm on the lines suggested by Robinson (1934), Coase (1937), Penrose (1955) and Williamson (1975) to take the advantage of economies of scale and arrest the problem of diseconomies of scale. This will certainly help the managers to maintain an appropriate level of profit rates. Also, the evidence on leverage-profit relationship suggests that managers may need to maintain an optimum level of debt-equity ratio to maximize firm value and minimize the cost of capital. Firms with high leverage ratios are perceived to have higher business risk and if investors are risk averters would subsequently require a higher return (risk premium) for taking on more risk which will further add cost to the cost of capital.

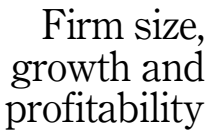

135 
EJMBE 31,1

\section{Notes}

1. The empirical studies related to firm size, growth and profits is vast and majority of them have also included concentration, competition barriers and other potential determinants of profitability. However, the same is not extensively reviewed as they fall beyond the scope of this work. The review in this section predominantly focuses on the important contributions that affect the empirical analysis of this study.

2. The Asia-Pacific economies are selected based on the availability of the data. For five Asian countries viz., China (2003-2016); Hong-Kong (1998-2016); India (2003-2016); Pakistan (1996-2016); Philippines (1996-2016)] the data on some of the firm specific variables is not available since 1995 whereas for rest of the seven economics viz. Indonesia (1995-2016); Israel (1995-2016); Japan (19952016); South Korea (1995-2016); Malaysia (1995-2016); Singapore (1995-2016) and Thailand (19952016)] complete data is available from 1995.

3. The measurement/definition of the selected variables is drawn from respective source of database.

4. Country-wise time series macroeconomic variable is culled from the World Development Indicators (WDI) of the World Bank.

5. Country-wise line plots of average ROA is given in Appendix.

6. High leverage benefits shareholders if profit exceeds borrowing costs (Goddard et al., 2005).

\section{References}

Agarwal, S. and Mohtadi, H. (2004), "Financial markets and the financing choice of firms: evidence from developing countries", Global Finance Journal, Vol. 15 No. 1, pp. 57-70.

Alchian, A.A. (1950), "Uncertainty, evolution, and economic theory", Journal of Political Economy, Vol. 58 No. 3, pp. 211-221.

Alexander, S.S. (1949), "The effect of size of manufacturing corporation on the distribution of the rate of return", The Review of Economics and Statistics, Vol. 31 No. 3, pp. 229-235.

Amato, L.H. and Amato, C.H. (2004), "Firm size, strategic advantage, and profit rates in US retailing", Journal of Retailing and Consumer Services, Vol. 11 No. 3, pp. 181-193.

Amato, L. and Wilder, R.P. (1985), "The effects of firm size on profit rates in US manufacturing", Southern Economic Journal, Vol. 52 No. 1, pp. 181-190.

Bain, J.S. (1951), "Relation of profit rate to industry concentration: American manufacturing, 1936-40", Quarterly Journal of Economics, Vol. 65 No. 3, pp. 293-324.

Bain, J.S. (1956), Barriers to New Competition, Harvard University Press, Cambridge.

Barney, J. (2001), "Firm resources and sustained competitive advantage: a ten-year retrospective on the resource based view", Journal of Management, Vol. 27 No. 1, pp. 643-650.

Baumol, W.J. (1959), Business Behavior, Value and Growth, Macmillan, New York.

Bowman, E. and Helfat, C. (2001), "Does corporate strategy matter?", Strategic Management Journal, Vol. 22 No. 1, pp. 1-23.

Brush, T., Bromiley, P. and Hendrickx, M. (1999), "The relative influence of industry and corporation on business segment performance an alternative estimate", Strategic Management Journal, Vol. 20 No. 6, pp. 519-47.

Capon, N., Farley, J.U. and Hoenig, S. (1990), "Determinants of financial performance: a meta-analysis", Management Science, Vol. 36 No. 10, pp. 1143-1159.

Caves, R.E. and Porter, M.E. (1977), "From entry barriers to mobility barriers: conjectural decisions and contrived deterrence to new competition", The Quarterly Journal of Economics, Vol. 91 No. 2, pp. 241-262.

Chandler, G.N. and Jansen, E. (1992), "The founder's self-assessed competence and venture performance", Journal of Business Venturing, Vol. 7 No. 3, pp. 223-236. 
Coad, A. (2007), "Testing the principle of growth of the fitter: the relationship between profits and firm growth", Structural Change and Economic Dynamics, Vol. 18 No. 3, pp. 370-386.

Coad, A. (2010), "Exploring the processes of firm growth: evidence from a vector auto-regression", Industrial and Corporate Change, Vol. 19 No. 6, pp. 1677-1703.

Coad, A., Rao, R. and Tamagni, F. (2011), "Growth processes of Italian manufacturing firms", Structural Change and Economic Dynamics, Vol. 22 No. 1, pp. 54-70.

Coase, R. (1937), “The nature of the firm”, Economica, Vol. 4 No. 16, pp. 386-405.

Cowling, M. (2004), “The growth-profit nexus”, Small Business Economics, Vol. 22 No. 1, pp. 1-9.

Deloof, M. (2003), "Does working capital management affect profitability of Belgian firms", Journal of Business Finance and Accounting, Vol. 30 Nos 3-4, pp. 573-588.

Demirguc-Kunt, A. and Maksimovic, V. (1996), "Stock market development and financing choice of firms", World Bank Economic Review, Vol. 10 No. 2, pp. 341-369.

Domowitz, I., Hubbard, R.G. and Petersen, B.C. (1986), "Business cycles and the relationship between concentration and price-cost margins", Rand Journal of Economics, Vol. 17 No. 1, pp. 1-17.

Fazzari, S., Hubbard, G. and Peterson, B. (1988), "Finance constraints and corporate investment", Brookings Papers on Economic Activity, Vol. 1 No. 1, pp. 141-206.

Gale, B.T. (1972), "Market share and rate of return", Review of Economics and Statistics, Vol. 54 No. 4, pp. 412-423.

Geroski, P.A. (1990), "Modelling persistent profitability", in Mueller, D.C. (Ed.), The Dynamics of Company Profits, Cambridge University Press, Cambridge, pp. 15-34.

Goddard, J., McMillan, D. and Wilson, J. (2005), "Do firm sizes and profit rates converge? Evidence on Gibrat's law and the persistence of profits in the long run”, Applied Economics, Vol. 15 No. 3, pp. 1269-1282.

Griliches, Z. and Lichtenberg, F. (1984), "R\&D and productivity growth at industry level: is there still a relationship?”, in Griliches, Z. (Ed.), R\&D Patents and Productivity, University of Chicago Press, Chicago, pp. 465-502.

Gschwandtner, A. (2005), "Profit persistence in the very long run: evidence from survivors and exiters", Applied Economics, Vol. 37 No. 7, pp. 793-806.

Gschwandtner, A. and Cuaresma, J.C. (2013), "Explaining the persistence of profits: a time-varying approach", International Journal of the Economics of Business, Vol. 20 No. 1, pp. 39-55.

Hall, M. and Weiss, L. (1967), "Firm size and profitability", Review of Economics and Statistics, Vol. 49 No. 3, pp. 319-331.

Hausman, J.A. (1978), "Specification tests in econometrics", Econometrica, Vol. 46 No. 6, pp. 1251-1271.

Hurdle, G.J. (1974), "Leverage, risk, market structure and profitability", The Review of Economics and Statistics, Vol. 56 No. 4, pp. 478-485.

Jang, S. and Park, K. (2011), "Inter-relationship between firm growth and profitability", International Journal of Hospitality Management, Vol. 30 No. 4, pp. 1027-1035.

Jean, W.V.H. (1970), The Analytical Theory of Finance: A Study of the Investment Decision Process of the Individual Firm, Holt Rinehart and Winston, New York.

Kaldor, N. (1966), "Marginal productivity and the macro-economic theories of distribution: comment on Samuelson and Modigliani”, The Review of Economic Studies, Vol. 33 No. 4, pp. 309-319.

Kamasak, R. (2017), “The contribution of tangible and intangible resources, and capabilities to a firm's profitability and market performance", European Journal of Management and Business Economics, Vol. 26 No. 2, pp. 252-275.

Lee, J. (2009), "Does size matter in firm performance? Evidence from US public firms", International Journal of the Economics of Business, Vol. 16 No. 2, pp. 189-203. 
EJMBE 31,1

Lippmann, S. and Rumelt, R. (1982), "Uncertain imitability: an analysis of interfirm differences in efficiency under competition”, The Bell Journal of Economics, Vol. 13 No. 2, pp. 418-38.

Long, J.S. and Ervin, L.H. (2000), "Using heteroscedasticity consistent standard errors in the linear regression model", The American Statistician, Vol. 54 No. 3, pp. 217-224.

MacKinnon, J.G. and White, H. (1985), "Some heteroskedasticity-consistent covariance matrix estimators with improved finite sample properties", Journal of Econometrics, Vol. 29 No. 3, pp. 305-325.

Mahoney, J. and Pandian, J. (1992), "The resource-based view within the conversation of strategic management", Strategic Management Journal, Vol. 13 No. 5, pp. 363-80.

Marcus, M. (1969), "Profitability and size of firm: some further evidence", The Review of Economics and Statistics, Vol. 51 No. 1, pp. 104-107.

Markman, G.D. and Gartner, W.B. (2002), "Is extraordinary growth profitable? A study of Inc 500 high growth companies", Entrepreneurship Theory and Practice, Vol. 27 No. 1, pp. 65-75.

Mendelson, H. (2000), "Organizational architecture and success in the information technology industry", Management Science, Vol. 46 No. 4, pp. 514-29.

Mueller, D.C. (1986), Profits in the Long Run, Cambridge University Press, Cambridge.

Mueller, D. (1990), "The persistence of profits in the United States", in Mueller, D.C. (Ed.), The Dynamics of Company Profits: An International Comparison, Cambridge University Press, Cambridge.

Myers, S.C. and Majluf, N.S. (1984), "Corporate financing and investment decisions when firms have information that investors do not have", Journal of Financial Economics, Vol. 13 No. 2, pp. 187-221.

Nucci, F., Pozzolo, A.F. and Schivardi, F. (2005), "Is firm's productivity related to its financial structure? Evidence from microeconomic data", Rivista di Politica Economica, Vol. 95 No. 1, pp. 269-290.

Penrose, E. (1955), "Limits to the growth and size of firms", The American Economic Review, Vol. 45 No. 2, pp. 531-543.

Porter, M.E. (1979), "How competitive forces shape strategy”, Harvard Business Review, Vol. 57 No. 2, pp. 37-145.

Prahalad, C. and Hamel, G. (1990), "The core competence of the corporation", Harvard Business Review, Vol. 68 No. 3, pp. 79-91.

Pusher, G. (1995), "Equity ownership structure leverage and productivity: empirical evidence from Japan pacific", Basin Finance Journal, Vol. 3 Nos 2-3, pp. 241-255.

Reid, G.C. (1995), "Early life-cycle behaviour of micro-firms in Scotland", Small Business Economics, Vol. 7 No. 2, pp. 89-95.

Robinson, A. (1934), "The problem of management and the size of the firm”, The Economic Journal, Vol. 44 No. 174, pp. 242-257.

Samuels, J.M. and Smyth, D.J. (1968), "Profits, variability of profits and firm size", Economica, Vol. 35 No. 138 , pp. 127-139.

Scherer, F.M. (1970), Industrial Market Structure and Economic Performance, Rand McNally and Company, Chicago.

Scherer, F.M. (1973), “The determinants of industrial plant sizes in six nations", Review of Economics and Statistics, Vol. 55 No. 2, pp. 135-45.

Serrasqueiro, Z.S. and Nunes, P.M. (2008), "Performance and size: empirical evidence from Portuguese SMEs", Small Bus Econ, Vol. 31 No. 2, pp. 195-217.

Shepherd, W.G. (1972), "The elements of market structure", Review of Economics and Statistics, Vol. 54 No. 1, pp. 25-37. 
Smith, V.H., Eriksson, M.T. and Madsen, E. (2004), "R\&D productivity in Danish firms: some empirical evidence", Applied Economics, Vol. 36 No. 16, pp. 1797-1806.

Stekle, R.H.O. (1964), "The variability of profitability with size of firms 1947-1958", Journal of the American Statistical Association, Vol. 59 No. 308, pp. 1183-93.

Firm size, growth and profitability

Stigler, G.J. (1963), Capital and Rates of Return in Manufacturing Industries, Princeton University Press, Princeton.

Stulz, R. (1990), "Managerial discretion and optimal financing policies", Journal of Financial Economics, Vol. 26 No. 1, pp. 3-27.

Verdoorn, P.J. (1949), "Fattori che regolano lo sviluppo della produttività del lavoro", L'Industria Vol. 1, pp. 3-11.

Wernerfelt, B. (1984), “A resource-based view of the firm”, Strategic Management Journal, Vol. 5 No. 2, pp. 171-180.

White, H. (1980), "A heteroskedasticity-consistent covariance matrix estimator and a direct test for heteroscedasticity", Econometrica, Vol. 48 No. 4, pp. 817-838.

Whittington, G. (1980), "The profitability and size of the UK co's 1960- 74", Journal of Industrial Economics, Vol. 28 No. 4, pp. 335-352.

Williamson, O.E. (1975), Markets and Hierarchies Analysis and Anti-trust Implications: A Study in the Economics of Internal Organization, The Free Press, New York.

Winter, S. (2003), "Understanding dynamic capabilities", Strategic Management Journal, Vol. 24 No. 10, pp. 991-6.

Yadav, I.S., Pahi, D. and Gangakhedkar, R. (2019), "Financial markets development and financing choice of firms: new evidence from Asia”, Asia-Pacific Financial Markets, Vol. 26 No. 4, pp. 429-451.

Yadav, I.S., Pahi, D. and Goyari, P. (2020), "The size and growth of firms: new evidence on law of proportionate effect from Asia”, Journal of Asia Business Studies, Vol. 14 No. 1, pp. 91-108.

\section{Corresponding author}

Inder Sekhar Yadav can be contacted at: yadavis@hss.iitkgp.ac.in 


\section{EJMBE Appendix \\ 31,1}
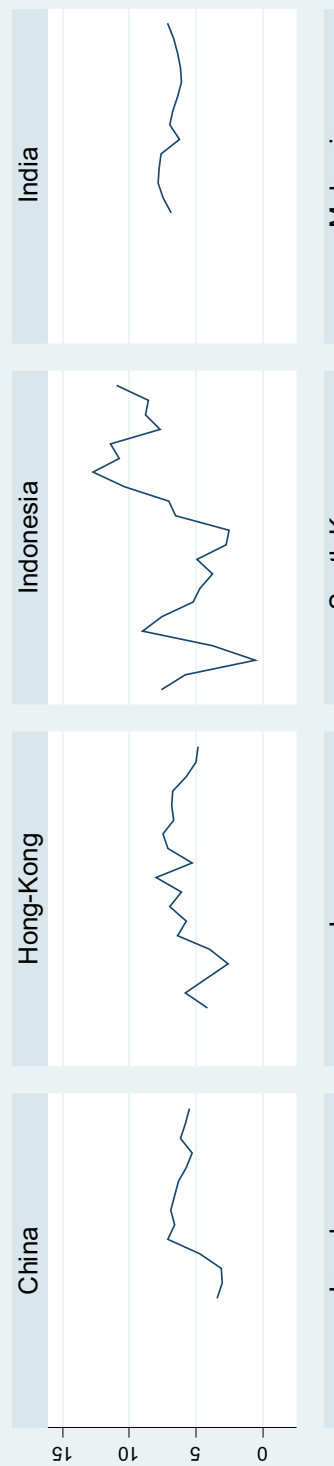

Figure A1.

Average return to assets. Country-Wise

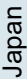

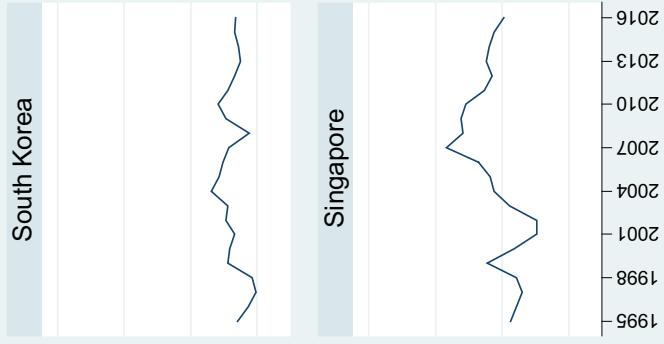

ڤั
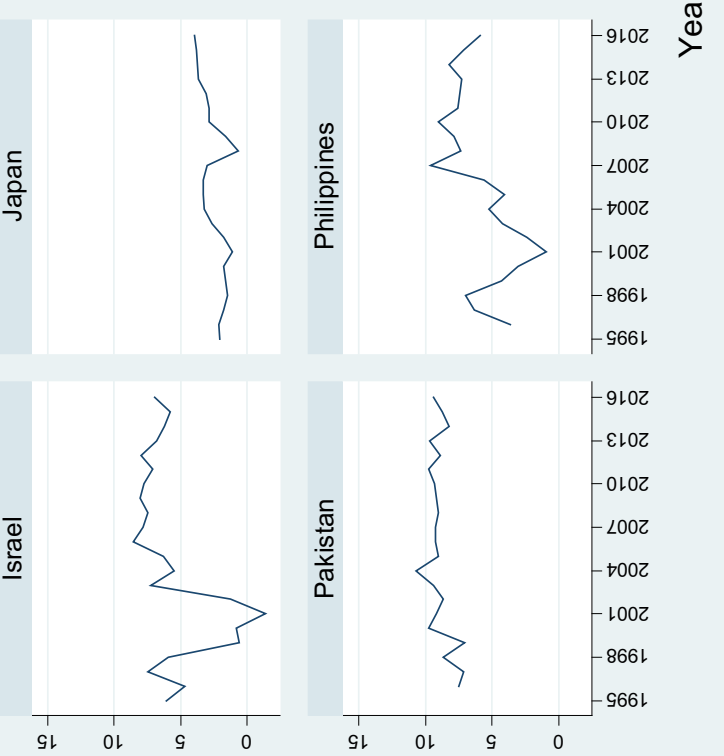

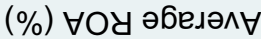
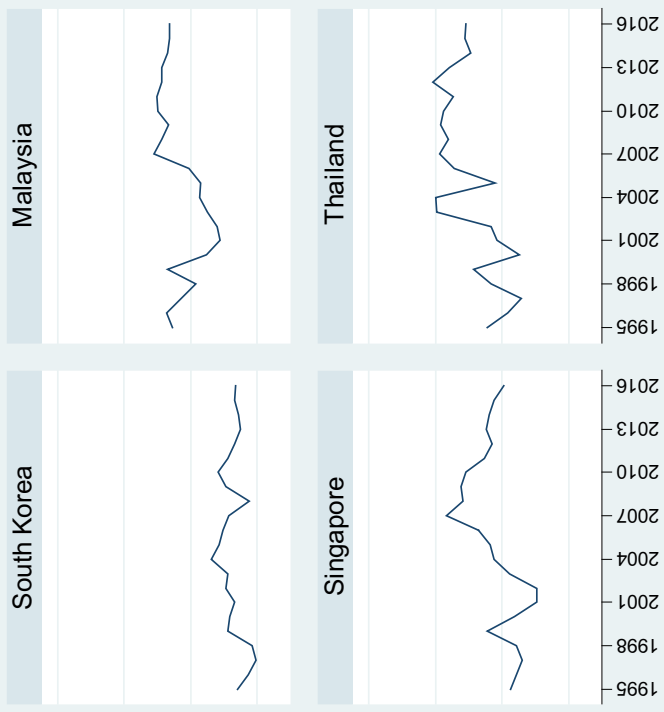

ঠัত
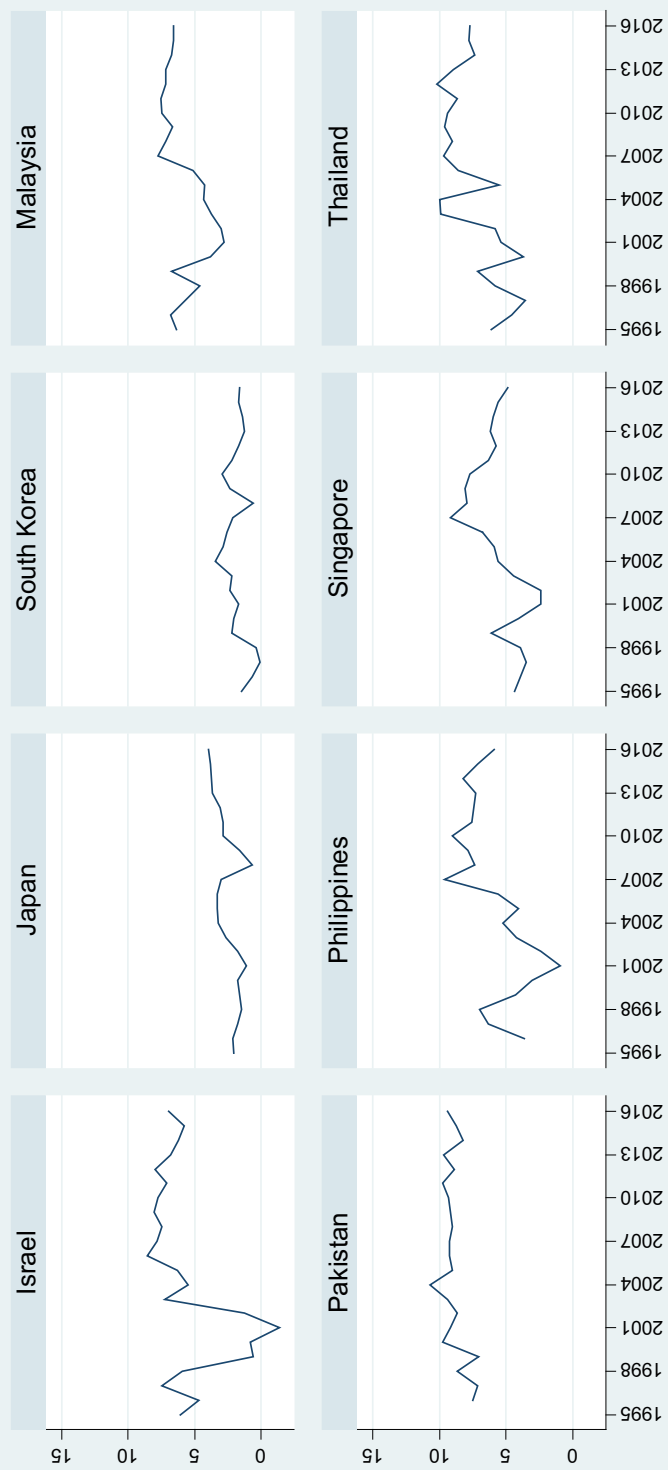

102
L0Z
002
002
002
661

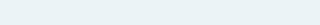

